\title{
Longest crab trackways from the Bay of Bengal Coast, India: Their geological and geotechnical applications
}

\author{
Chirananda De
}

\begin{abstract}
Neoichnological appraisal of amphibious side-runner crab Ocypode produced on the Bakkhali beach in eastern India has revealed how animal physiology, life-habits and substrate decide architecture, orientation, continuity, morphological variations and preservation potential of their typically asymmetric trackways. About $100 \mathrm{~m}$ long, seaward moving, parallel and cross-coast trackways that constitute the world's longest ever known invertebrate trackways amongst modern and ancient records are generated selectively by adults while herding down beach slope in quest of life-saving seawater to moisten their gills. Smaller, freely-wandering and self-crossing trackways in the moist intertidal flat are produced by young while searching food, making pellets and runways, and escaping from predators. The unnamed asymmetric crustacean trackways of Eocene of Andaman and Quaternary Banas Basin of India constitute ancient analogues of the Ocypode trackways. The analogy and fossil arthropod trackways as delicate as the present ones justify their preservation potential. The palaeoichnological applications include ichnotaxonomic revisions, creation of new ichnotaxon as taphonomic and ethological variants, and taxonomic identification of ancient trace makers, besides palaeoecological and palaeogeomorphic interpretations. It relates animal physiology with ichnotaxonomy in detail, provides new information to the existing database, and bears application potential in coastal geotechnical programmes as a new ichnological tool.
\end{abstract}

Chirananda De. Geological Survey of India, Palaeontology Division, Western Region, 15 - Jhalana Dungri, Jaipur 302015, Rajasthan, India. chirananda@rediffmail.com

Keywords: Ocypode; longest trackways; applications; geology; geotechnology

\section{INTRODUCTION}

Locomotion traces or trackways, both recent and ancient, of vertebrates and invertebrates are reported from a myriad of sedimentary environ- ments. Of these, the records of vertebrate trackways certainly outnumber that of the invertebrates. The fossilized vertebrate (e.g., dinosaurs, birds, fishes, amphibians and mammals including elephant, ruminant goat and even human) trackways

PE Article Number: 17.2.31A

Copyright: Palaeontological Association August 2014

Submission: 20 April 2013. Acceptance: 27 July 2014

De, Chirananda. 2014. Longest crab trackways from the Bay of Bengal Coast, India: Their geological and geotechnical applications. Palaeontologia Electronica Vol. 17, Issue 2;31A; 19p; 
are recorded from continental playa-lake (Scrivner and Bottjer, 1986), carbonate aeolianite (Fornós et al., 2002; Roberts et al., 2008), terrestrial (Sarjeant and Mossmann, 1978; Demathieu and Wycisk, 1990; Min Huh et al., 2006; Lockley et al., 2006a; Kim et al., 2008; Lee et al., 2008), glaciolacustrine (Benner et al., 2008), lacustrine (Pollard and Hardy, 1991; Genise et al., 2009), fluvio-lacustrine (Costa da Silva et al., 2008), interdune (Gradziński and Uchman, 1994; Jacobs and Roberts, 2009), marginal marine shoreline (Lockley et al., 2006b; Anfinson et al., 2009), tidal flat (Diedrich, 2008) and volcano-sedimentary (Ataabadi and Sarjeant, 2000) facies. Dinosaur tracks have been found in over 1000 locations throughout the world, on every continent except Antarctica (Kuban, 2009). Contrastingly, the invertebrate (largely arthropods including eurypterids, myriapods and trilobites) fossil trackways are restricted to finer clastics of backshore-foreshore (Draganits et al., 1998), paralic (Braddy and Almond, 1999) and lacustrine (Pollard and Hardy, 1991; Seilacher, 2008) environments. Growth of biomats usually provides excellent substrate conditions through the formation of leathery semi-rigid top layers for survivorship and preservation of delicate trackways especially in the postProterozoic sediments (Seilacher, 2008) following the Cambrian organic explosion and development of Hox gene-controlled hard body parts (Schopf and Klein, 1992).

Study of fossil trackways, as a whole, has remained important as they reveal various ichnotaxonomic (Lockley et al., 2006a, 2006b; Davis et al., 2007), ethological (Braddy and Almond, 1999; Min Huh et al., 2006; Benner et al., 2008; Kim et al., 2008; Genise et al., 2009), anatomical (Clack, 1997), palaeoecological and palaeoenvironmental (Demathieu and Wycisk, 1990; Fornós et al., 2002; Lockley et al., 2006a), palaeogeographical (Diedrich, 2008), colonization (Gradziński and Uchman, 1994; Draganits et al., 1998) and evolutionary (Scrivner and Bottjer, 1986; Anfinson et al., 2009) aspects of the ancient trackway producers. On the other hand, neoichnological appraisal of modern trackways for palaeoichnological applications and other geological interpretations is extremely rare in published literature. Neoichnological observations on the behavioral patterns of modern shorebirds (sandpipers Calidris bairdii and Calidris fuscicollis) that seasonally frequent coastal freshwater ponds (Bajo de los Huesos, Chubut) of Argentina have helped interpret avian trackway affinity of the ichnotaxon Gruipeda dominguensis described from the Late Triassic-Early Jurassic Santo Domingo
Formation (Genise et al., 2009). An experimental neoichnological study on the effects of varied substrate conditions on the morphology and preservation of modern terrestrial arthropod trackways reveals that the combined effect of increasing concentrations of clay minerals and surface moisture provides excellent conditions for trackway survivorship and preservation (Davis et al., 2007). Moreover, there remain wide gaps in our understanding of the controlling factors (e.g., physiological need, substrate conditions, biomat development, erosional forces, bauplan of the appendages and many others) that decide formation, induce ichnotaxonomic variations and favor preservation of bewildering array of modern tracks and trackways in any given environmental setting and in successful application of these neoichnological data into geological past and present geotechnology.

The present paper deals with the factors governing the formation, variation in forms and preservation of the world's longest modern decapod crustacean trackways across the Bakkhali beach, Bay of Bengal coast of West Bengal, eastern India, and addresses their multiple application to geological past and modern geotechnology, especially with reference to delta front coastline settings.

\section{SITE DESCRIPTION}

The Bay of Bengal coast borders the southern fringe of the world's most colossal mangrove delta complex of Sundarban (Figure 1) in eastern India. It harbors a wide range of trace-forming invertebrates and vertebrates. The distinctive sedimentary environments include estuary, backswampsaltmarsh-mudflat complex, coastal beach-dune complex, supratidal-intertidal-subtidal beaches, tidal flats, long shore and channel-mouth bars, and distant partially submerged islands (Figure 1). The conspicuous coastal landforms (Reineck and Singh, 1973; De, 2000, 2003a, 2005a) developed in the Bakkhali area include lower estuarine zone, back dunal mudflats-backswamps-saltmarsh-creek complex with thick mangrove vegetation, older stabilized dune ridges, younger mobile dunes and sand sheets, low gradient supratidal and intertidal beaches from land to sea (Figure 1).

The sediments of the study area (Figure 2) show limited variation in grain size (clay to coarse sand) and firmness (soft ground). The sediments of the lower estuarine zone are predominantly thinlybedded to parallel-laminated clay-silt in the floodplains, fine to medium sand in the channel bars, and alternately laminated sand-silt-clay in the natural levees. The swamps associated with aban- 

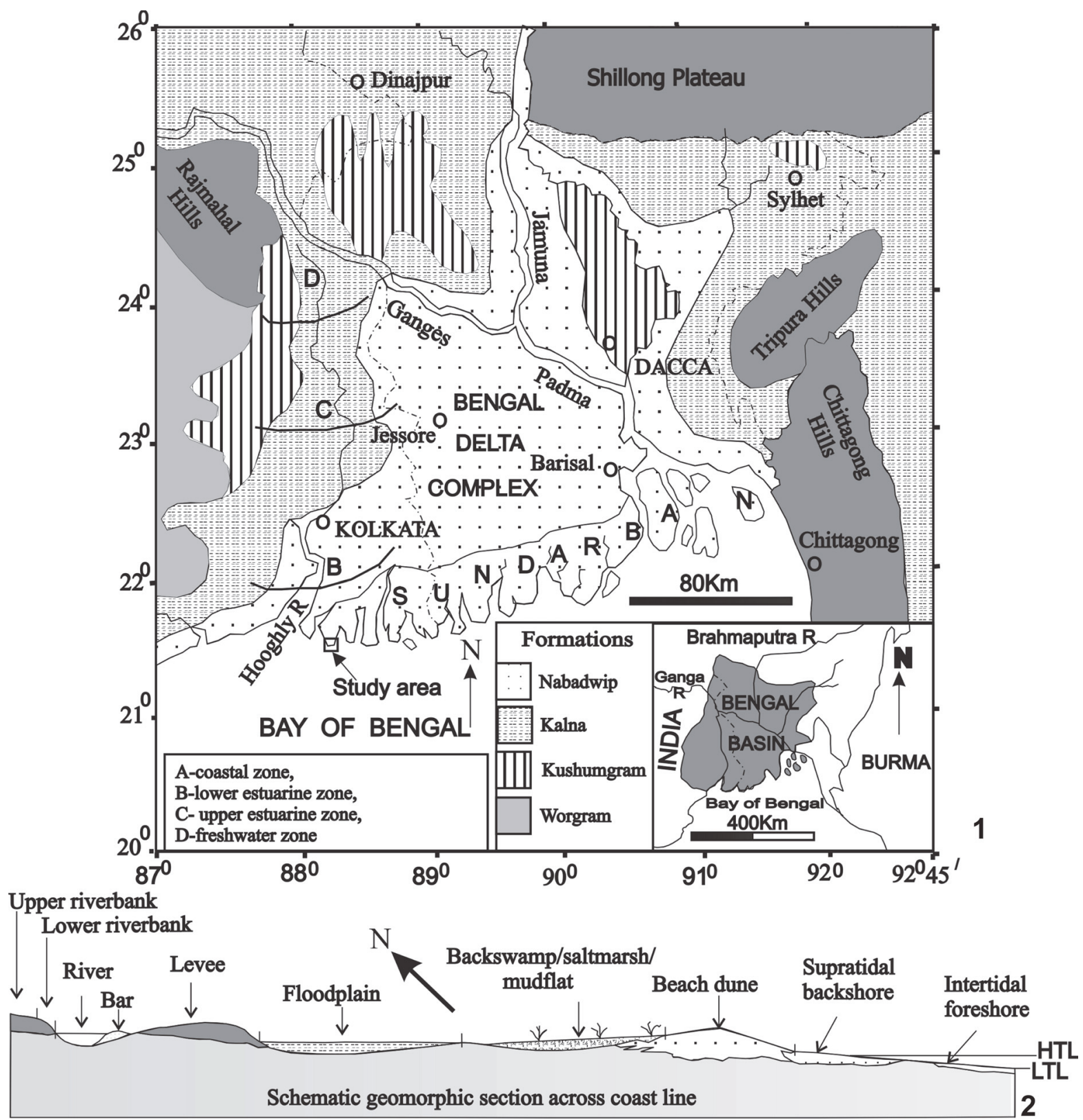

FIGURE 1. General geological and geomorphological map of Sundarban Delta Complex showing present extent of mangrove forest, regional stratigraphy, geomorphic units and the location of the studied Bakkhali beach sector (1). A schematic coastal profile (2) is drawn to show distribution of different coastal geomorphic units from land to sea.

doned channel courses are filled with soft grayishblack clays and silts. Grain size measurements indicate predominance of clay-silt over sand in the coastal mudflats, backswamps, salt marshes and creek banks. The coastal dunes, supratidal backshore and intertidal foreshore beaches are composed mainly of grey, black and purple sand, and silt admixed in various ratios (calculated MZ 2.75 phi to 1.4 phi). Microbial (algal) mats or biomats are developed locally in patches in the moist and depressed areas on the supratidal flats (Figure 2).
A few millimeter thick leathery and slightly coherent admixtures of fine sand, silt and green algaesecreted organic glue define the matground. Various types of delicate traces are found preserved in the biomats under thin cover of fine wind-settled sediments. Biomats are often destroyed during monsoons and spring tides.

The average rate of net sedimentation in the Bay of Bengal coast was calculated to be $6.7 \mathrm{~cm} /$ 100 years by Mallick (1976). The area exhibits a wide range of primary sedimentary structures, for 


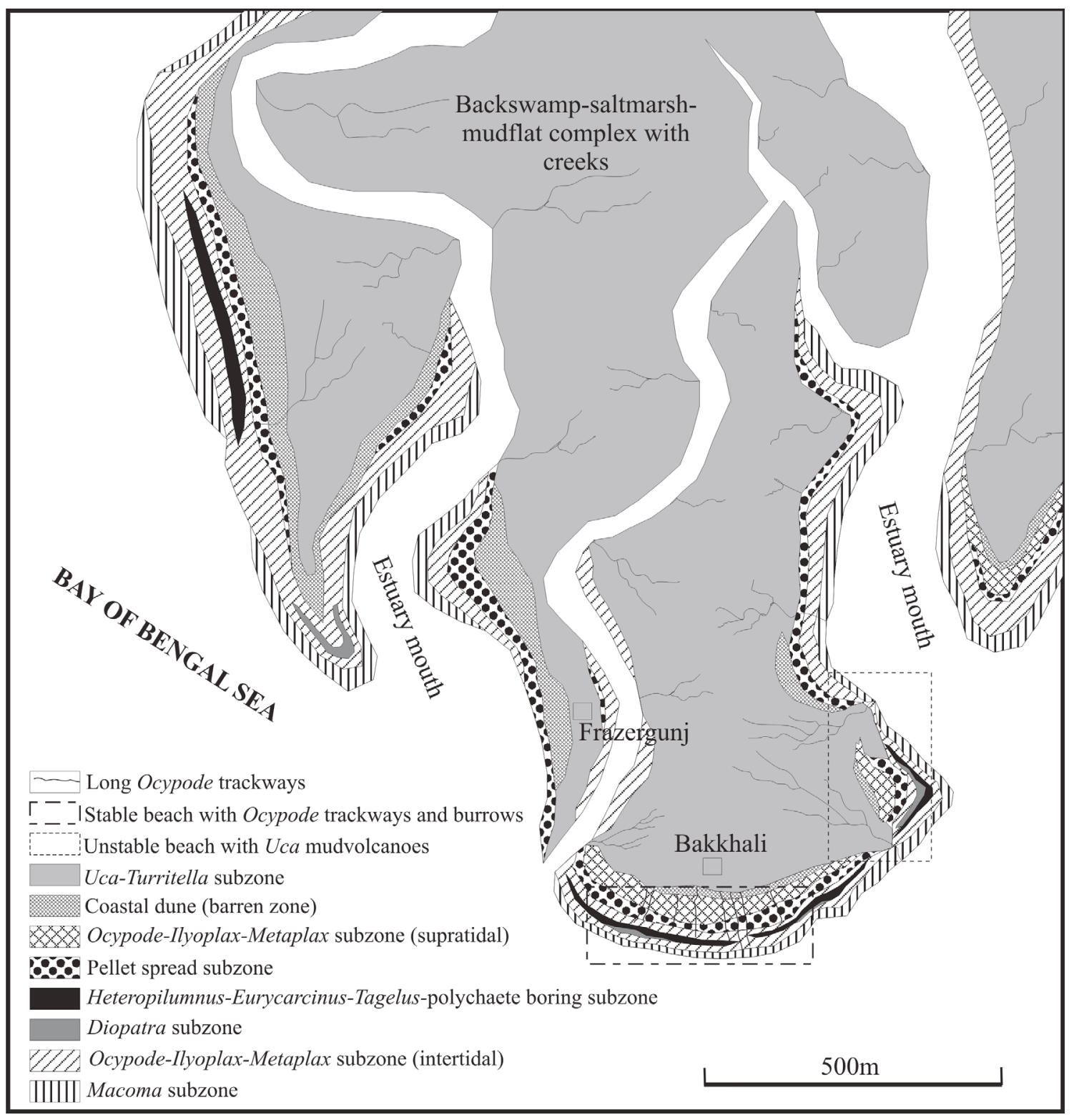

FIGURE 2. Geological and geomorphological map of the Bakkhali beach showing different ichnological subzones, location of long trackways, and stable and unstable beach segments.

example, various types of cross-beddings, ripples (wave, current, interference, double crested and low amplitude), rill marks, scour marks, wrinkle marks (probably biomat-related), aeolian current lineation, mud balls, desiccation cracks, hummocky cross-stratification and aeolian dunes. The tidal flats exhibit various types of ripples (lunate, linguoid, current, wave, etc.) with truncated crests, ripple-drift laminations, rill marks, flaser beddings, rhythmic laminations and herringbone cross beds. The aeolian dune sands show wedge-shaped high angle cross beds and gravitative slump structures. The hydraulic energy level in the estuary zone is low to moderate. It increases drastically towards the open coast where wave, tide and wind actions, and occasional storm conditions prevail. Effect of wave action is most conspicuous on the beaches and breaker zones.

The region experiences average maximum and minimum temperature of $42^{\circ} \mathrm{C}$ (May to June) and $22^{\circ} \mathrm{C}$ (December), moderately high annual rainfall $(1490 \mathrm{~cm}$ to $2430 \mathrm{~cm})$, a high salinity range ( $23 \%$ in the inner vs. $39 \%$ in the outer delta), moderate $\mathrm{pH}$ (7.7 to 8.4), and a mean maximum semidiurnal spring tidal range of $6.8 \mathrm{~m}$ to $7.7 \mathrm{~m}$ and mean minimum neap tidal range of $2.2 \mathrm{~m}$ to $2.5 \mathrm{~m}$ 
(Port Trust of India database for the last five years). The dissolved oxygen content in open seawater ranges from $2.4 \mathrm{ml} / /$ to $4.7 \mathrm{ml} / \mathrm{l}$ (Chattopadhaya et al., 1993). Predominant wind directions are from south to north (March to October) and are reversed during November to February. Pre-monsoon tropical cyclones, locally called "Kalbaishakhi" (southeast to northwest, $80 \mathrm{~km} / \mathrm{hr}$ to $120 \mathrm{~km} / \mathrm{hr}$ and two to four times/month from March to May), reorganize the beach and dune sands. Non-storm shallow waves ( $0.5 \mathrm{~m}$ to $7 \mathrm{~m}$ wavelength) approach the beach at $70^{0}$ to $85^{0}$.

The study area (Figure 2) represents a part of subtropical, littoral and marine-estuarine mangrove ecosystem developed in hot, humid, saline and marshy environments where about $20 \%$ to $40 \%$ of the land area gets inundated during high tides. Due to the abundance of food and shelter, and low predation pressure, mangroves are known to form ideal nursery habitats for a variety of animal species, e.g., crab, prawn and fish species (Nagelkerken et al., 2008). The ecosystem sustains diversified faunal communities that include mammals, birds, reptiles, amphibians, fishes, insects and other invertebrates besides various types of microorganisms. Amongst the invertebrates, the most dominant groups are insects, arthropods, annelids and mollusks. They thrive in large numbers in the riverbanks, swamps, marshes, creek banks and beach profiles. Of the lebensspurenproducing endobenthic invertebrate communities, the decapod crustaceans (crabs) are most predominant and omnipresent followed closely by polychaete worms and mollusks (gastropods and bivalves). About 86 decapod crustacean species belonging to 13 families are known from the coastal Bengal (Deb, 1998). These are associated with 16 molluscan species, most of which produce traces. The published documents covering the study area on the biophysical mechanism of intertidal beach crab burrowing and environmental ichnozonation of the trace producers (De, 2005a, 2009a), crab burrowing and pellet making activities (De, 2000), ichnological evidences of rising sea level (De, 2002b, 2003a; Bandopadhaya and De, 2000), burrowing habits of bivalve Macoma birmanica Phillipi (Chattopadhaya et al., 1993 ) and geotechnical applications of ichnological tools (Diopatra cuprea Bosc tubes and Uca mud volcanoes: De, 2002a, 2009a) have revealed high neoichnological potentiality of the Bay of Bengal coast in West Bengal.

The Bakkhali beach (Figure 2), in particular, has long been considered as an excellent natural laboratory to experiment with a myriad of amazing organo-sedimentary features (lebensspuren) that are being formed round the clock, destroyed by each wind and wave action and preserved under each sediment layer. The interaction among animal physiology and environment is responsible for a wide range of biogenic structures, from submicroscopic borings on ooids to vertebrate and decapod trackways (Bandopadhaya and De, 2000) to as long and robust as stampeding trackways or footprints particularly of vertebrates and decapod crustaceans (De, 2000, 2005a). This beach exhibits development of a wide variety of trackways particularly during the morning hours on moist medium to fine sands admixed with variable amounts of clay and xylic contents. During the daytime with the increase in wind velocity and decrease in sediment moistness, these trackways get highly modified and/or largely destroyed. In spite of the abundant and diversified trackways in the Bakkhali beach, these features have remained, so far, unaddressed in the published literature on the studied area. Martin (2006) from Sapelo Island (Georgia, USA) discussed resting traces and connected trackways of modern ghost crab Ocypode quadrata with emphasis on physiological (hydration and respiration in intertidal environment) and preservation aspects. Netto and Grangeiro (2006) addressed modern Psylonichnus ichnocoenosis defined by various types of burrows and trackways of crabs (including Ocypode quadrata) and tracks of beetles, birds and lizards developed in the seaward side of the Peixe Lagoon of southern Brazil with reference to their preservation potential, palaeoenvironmental and stratigraphic significances. Unlike the above two works, the present paper addresses the details of morphological changes of trackways of the crab Ocypode vis a vis substrate environments, physiological needs and preservation potential in terms of Geological and geotechnical significance.

\section{MATERIALS AND METHODS}

The materials of the present study include various trackways of the crab Ocypode, substrate conditions in terms of sand-silt-clay and moistness and their photographic documentations. During a field visit to the Bakkhali beach the author early in the morning of July 3, 2010, during neap low tide came across several unusually long, sinuous to straight and just-made trackways of crabs on the soft beach sediments. These continuous trackways were traced right down the beach slope (down going) and across the entire shoreline. However, a few similar trackways of shorter lengths $(40 \mathrm{~m}$ to 
$50 \mathrm{~m}$ ) were observed to be disposed oppositely (up-coming) in the intertidal flat. The longest continuous one (down going) was measured to be 115 $\mathrm{m}$ long and $8 \mathrm{~cm}$ wide. It appeared from a burrow opening located in the supratidal back dune complex and continued over dry to moist rippled sand surfaces of the dunes and supratidal-upper intertidal zones before vanishing into seawater in the middle intertidal zone (Figure 3.1). Seven more morphologically similar trackways (down going) with semi-parallel trends were also observed in close vicinity. The length vs. width of these associated trackways measures to be $95 \mathrm{~m}$ vs. $8 \mathrm{~cm}, 97$ $\mathrm{m}$ vs. $8.2 \mathrm{~cm}, 89 \mathrm{~m}$ vs. $8 \mathrm{~cm}, 84 \mathrm{~m}$ vs. $7.8 \mathrm{~cm}, 67 \mathrm{~m}$ vs. $8.1 \mathrm{~cm}, 59 \mathrm{~m}$ vs. $8.3 \mathrm{~cm}$ and $92 \mathrm{~m}$ vs. $7.7 \mathrm{~cm}$. Interestingly all these eight trackways originate from different points (dwelling burrows) on the supratidal back dunes and head downwards towards the then seawater level right along the beach slope covering shortest possible distances to meet the seawater. The length of the trackways, thus, varies with the position of the dwelling burrow (point of initiation), seawater (tide) level on the local beach profile at the time of locomotion, tidal cycle and beach slope. Moreover, a general consistency has been observed in the trackway width $(7.7 \mathrm{~cm}-8.3 \mathrm{~cm})$ that seems to be related to similar body size or in other words to a particular ontogenetic growth stage of the walking crabs. It was reported previously (De, 2000) that the supratidalintertidal Bakkhali beach is dwelled by a thick population of semi-terrestrial ocypodid crabs (Ocypode spp., Ilyoplax pusillus Tweedie and Uca marionis Alcock). The first two produce dwelling burrows in the sandy supratidal and intertidal zones, while Uca (2 cm $-3 \mathrm{~cm}$ across) along with Turritella prefers to dwell in muddy backswamps and creek banks (Figure 2; De, 2000). The above study has also revealed that Ocypode spp. together with Ilyoplax and Metaplax produce coast-parallel ontogeny-based linear burrow zones (Figure 2; De, 2009a). The intertidal part is generally dwelled by young individuals, while the old individuals together with adult (both male and female) and juvenile crabs exploit the supratidal beach and produce long, thick and interconnected burrows with brood chambers and rising juvenile shafts for community dwelling purpose (De, 2000, 2005a). The tiny crab llyoplax pusillus (few millimeter across), on the other hand, defines a narrow coast-parallel zone of short and thin thread-like burrows within the supratidal beach (De, 2005a, 2009a). The body lengths of adult and old individuals of Ocypode ceratophthalma Pallas, O. stimpsoni Ortmann and O. mac- rocera Edwards in walking posture (with unfolded legs) have been measured to be $7.2 \mathrm{~cm}-8.5 \mathrm{~cm}$, $6.9 \mathrm{~cm}-8.4 \mathrm{~cm}$ and $7.5 \mathrm{~cm}-9 \mathrm{~cm}$, respectively. Since all these crabs are side runners, their body length in walking mode corresponds to the width of the trackways. Of these three genera, only the body size of adult and old Ocypode crabs corresponds to the observed general width $(7.7 \mathrm{~cm}-8.3$ $\mathrm{cm}$ ) of the trackways. Since physiological energy requirement to produce such long repichnial trackways is too high to be possessed by the old and juvenile crabs, the present trackways are in all probability produced by the adult individuals of Ocypode spp. In the field, some juvenile individuals of Ocypode were observed to produce similar but narrower trackways while straying over the proximal intertidal moist sand beds. The trackways are associated with footprints of praying birds (Figures $3.1,4.3)$ and trackways of other invertebrates.

\section{THE DECAPOD CRUSTACEAN TRACKWAYS}

Moist intertidal sands optimally record trackway morphology (Figures 3.3, 4.1-5). The best impressed trackway is composed of slightly alternately placed crescent grooves of dissimilar dimensions and depths. The grooves are arranged biserially along the trackway and bordered around by pushed up sand rims collectively resembling a chain structure (Figure 4.1-4). A narrow but discontinuous and sinuous sand ridge separates two series of crescent groves on either side (Figure 4.1-2). One series contains two rows of grooves. The grooves in the inner row of this series are larger and deeper, while those in the outer row are smaller, narrower and shallower. The other series contains deepest grooves one touching the other obliquely and arcuately in a single row. This difference imparts diagnostic morphological asymmetry. The pushed up sand rims and inside grooves show strong forward curvature such that their narrower ends point backward (Figure 4.1-5). These structural clues to the direction of movement suggest general seaward locomotion (herding) of the Bakkhali Ocypode crabs.

The trackway morphology, however, changes substantially along its length depending on substrate conditions. On very moist sand beds in the lower intertidal part (Figures 3.4, 5.1-2) the central narrow ridge, marginal groves and arcuate ridges become indistinct, although biseriality and morphological asymmetry of the trackways can be recognized. The indistinctiveness is because of instant partial collapse of water laden sandy groves and ridges. The trackways on dry supratidal sands (Fig- 


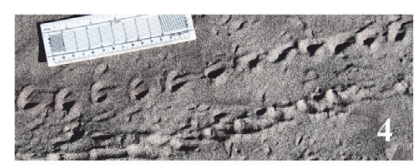

In very moist sand

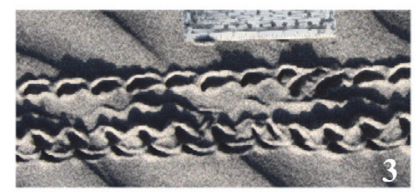

In moist sand

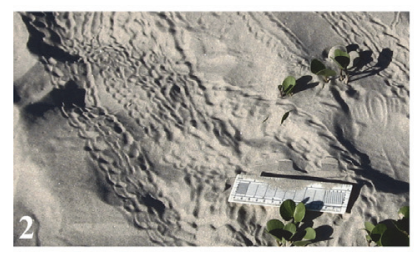

In dry sand
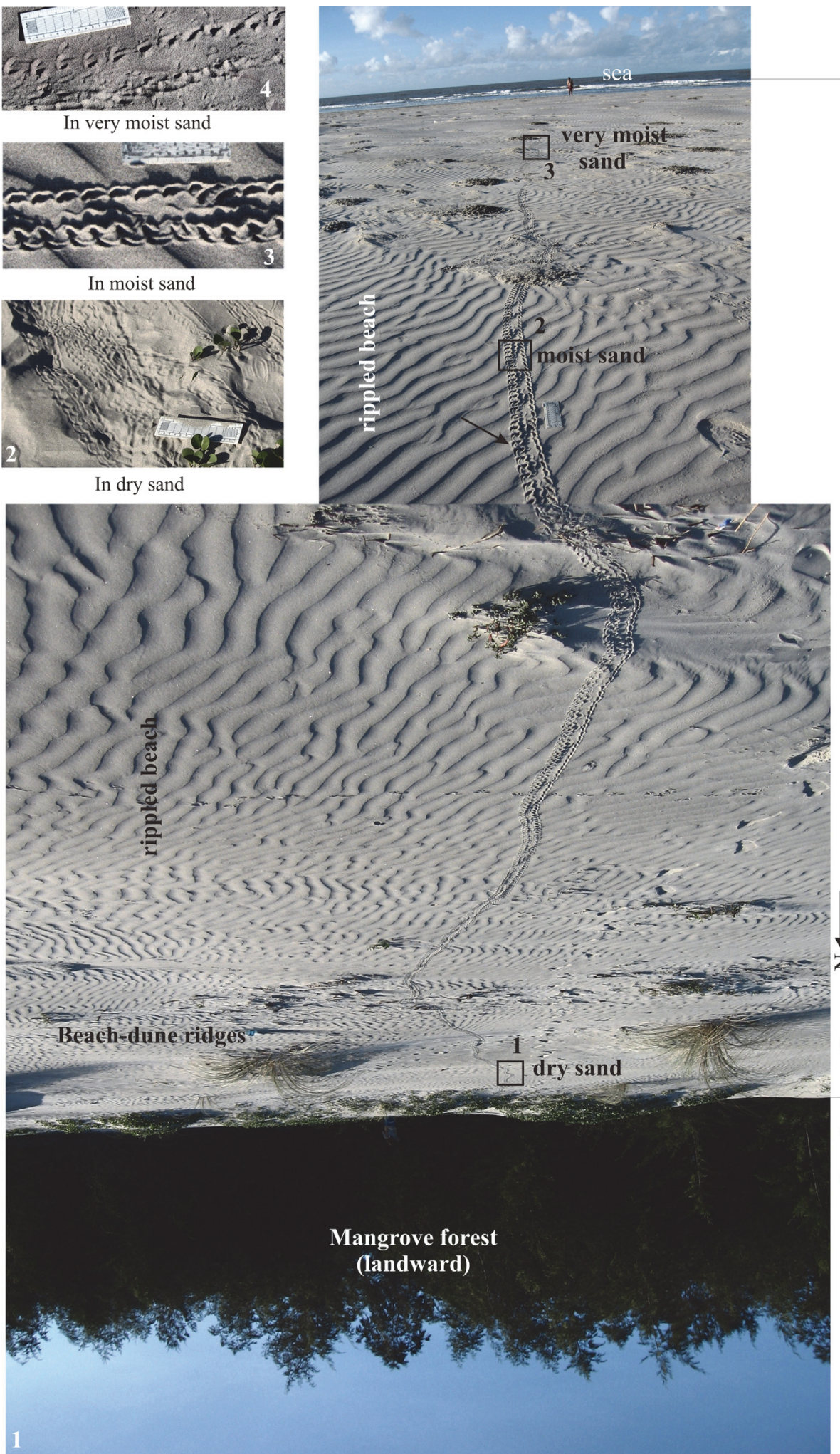

FIGURE 3. Distant view of the longest observed Ocypode trackway (shown by arrow). Note the positions of land and sea, trackway continuity, trackway maneuvering, and trackway morphology in different geomorphic units (1), Ocypode trackways on dry supratidal sand (2), best engraved trackway in moist sand of middle intertidal flat (3), trackway in very moist sands of lower intertidal flat (4). Note substrate specific morphological variations of the trackways. The scale measures $16 \mathrm{~cm}$. 

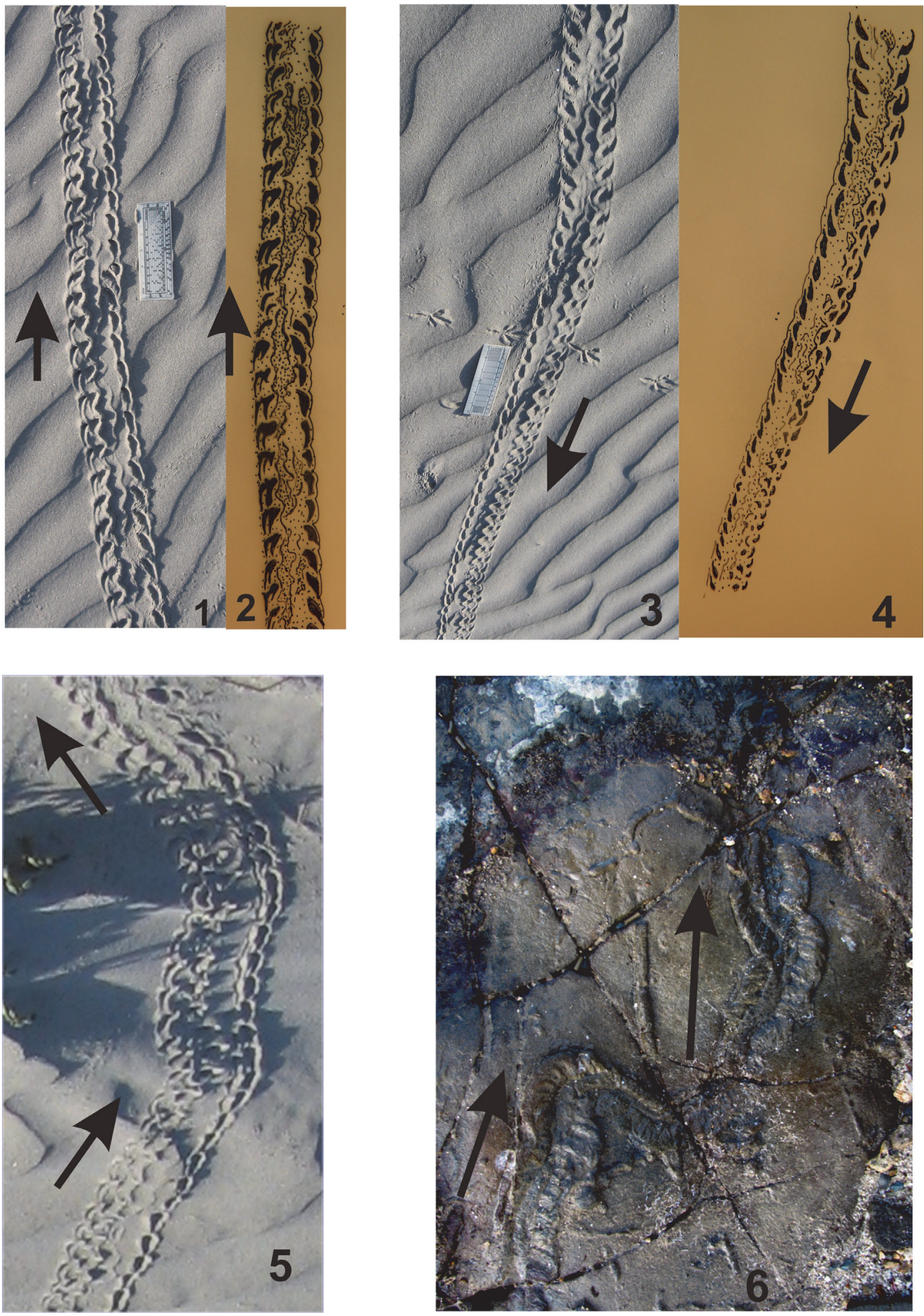

FIGURE 4. Close views and line drawings of best produced trackways for morphological details. Arrow heads indicate the direction of movement: moving upward trackway (1) and its line drawing (2), moving downward crab trackway (3) overprinted by bird trackway and its line drawing (4), trackway moving zigzag maneuvering mangrove bushes on the left (5) and fossilized decapods trackways from Eocene Mithakhari Group of Andaman Islands (6), the closest possible ancient analogue of the describe modern longest crab trackways from Bay of Bengal coast. The scale measures $16 \mathrm{~cm}$. 

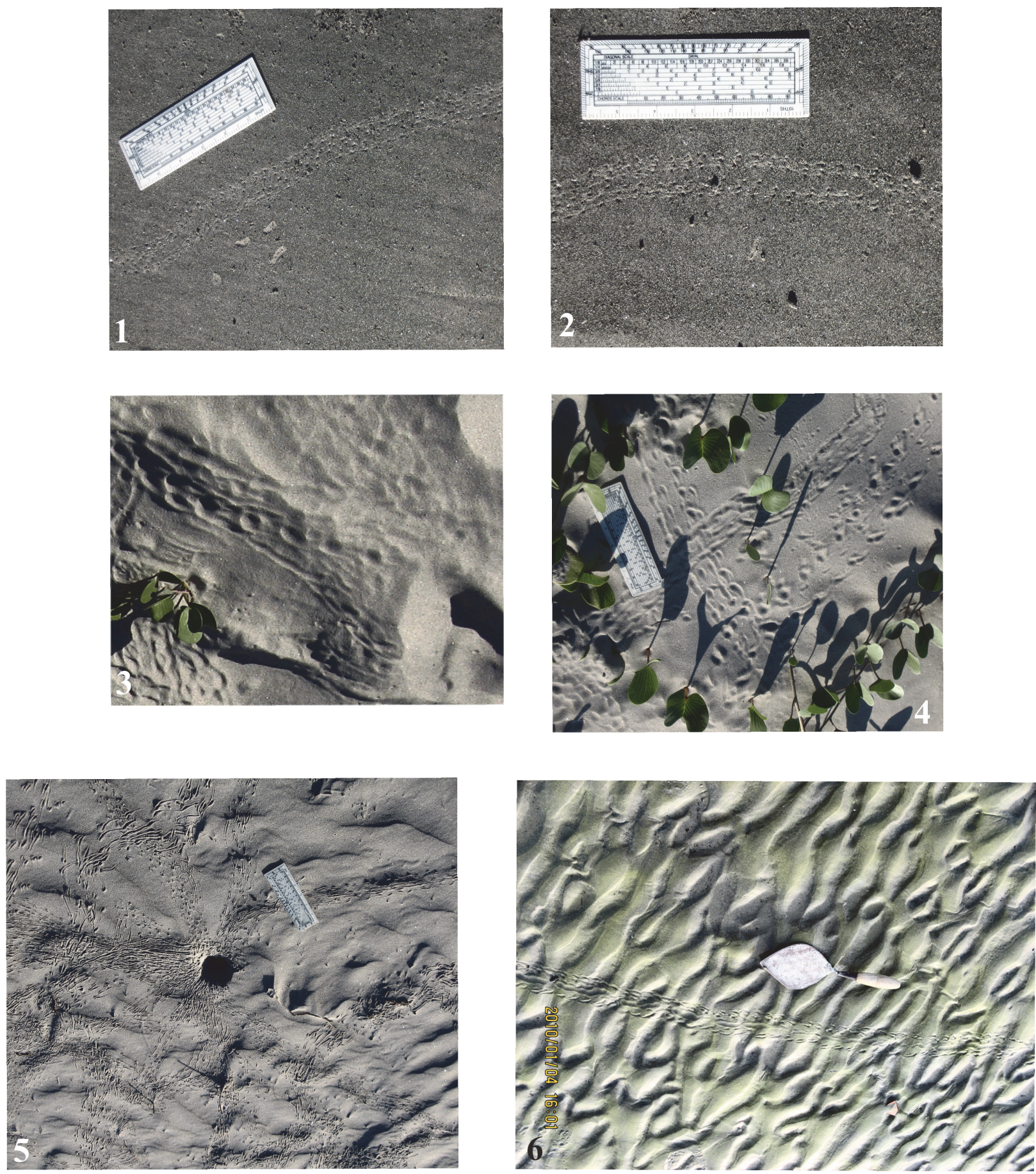

FIGURE 5. Photographs show variations in trackway morphology. Trackways produced on very moist substrate of lower intertidal flat - note morphological indistinctiveness (1-2); trackway made on dune slope - note morphological changes due to sliding effect (3); trackways produced on dry and flat sand surface - note their different appearance (4); shorter, narrower, freely wandering, and self-crossing young Ocypode trackways produced around a burrow opening in the moist middle intertidal flat as a result of searching food and feeding pellet making activity (5); long trackway produced on extra rigid and sticky biomat substrate in the supratidal depression - note different morphological appearance relative to the others (6). The scale measures $16 \mathrm{~cm}$. 
TABLE 1. Bibliographic review of fossil trackways and their interpretations.

\begin{tabular}{|c|c|c|}
\hline Palaeoichnological features & $\begin{array}{c}\text { Interpretations } \\
\text { (locomotion styles, behavior, } \\
\text { taphonomy, physiology etc.) }\end{array}$ & References \\
\hline Cruziana of Cambrian-Ordovician trilobite origin & Different swimming-walking styles & Crimes, 1975 \\
\hline $\begin{array}{l}\text { Millions of small- to medium-sized reptile } \\
\text { trackways from Early to Middle Triassic carbonate } \\
\text { tidal flats in the Germanic Basin, central Europe }\end{array}$ & $\begin{array}{l}\text { Collectively attributed to emigration through inter- } \\
\text { peninsular bridges exposed during low sea stands }\end{array}$ & Diedrich, 2008 \\
\hline $\begin{array}{l}\text { Tetrapod footprints and trackways along with } \\
\text { profuse arthropod traces found in the interdune } \\
\text { deposits of the Lower Triassic Tumlin Sandstone of } \\
\text { Central Poland }\end{array}$ & Rapid colonization of interdunes & Gradziński and Uchman, 1994 \\
\hline $\begin{array}{l}\text { A large variety of Lower Palaeozoic Trilobite } \\
\text { trackways }\end{array}$ & $\begin{array}{l}\text { Different types of locomotion such as walking, } \\
\text { grazing, galloping, fast and slow sidling, walking - } \\
\text { swimming etc. }\end{array}$ & Seilacher, 2007 \\
\hline Climatichnites & $\begin{array}{l}\text { Surface tracks and trails of mollusk having } \\
\text { physiological capacity to manipulate sediment to } \\
\text { produce the structure }\end{array}$ & Getty and Hagadorn, 2005 \\
\hline Shoreface crab resting traces & Resting patterns, hydration and respiration & Martin, 2006; Minter et al., 2007 \\
\hline $\begin{array}{l}\text { Aestivation burrows of lungfish, earthworm, } \\
\text { lysorophid and dicynodont }\end{array}$ & $\begin{array}{l}\text { True physiological need of retaining body water } \\
\text { content during extremely dry (draught) situation }\end{array}$ & Hembree, 2010 \\
\hline
\end{tabular}

ure 3.2) are distinctly asymmetrical and run right across the beach trend maneuvering irregular obstructions. Biserially arranged arcuate pedal groves and central discontinuous linear ridges (Figure 3.2) become indistinct. Trackways over dune slopes show the sliding effect of the groves and ridges producing marginally long and narrow depressions created by coalesced groves (Figure 5.3). Those produced on flat and dry sand surfaces show no sliding effect and the structure looks different (Figure 5.4). The formation of morphological asymmetry and biseriality of the trackways, irrespective of substrate conditions, has been attributed to the known side-wise running life habit of the Ocypode crabs. Trackways, as observed in the study area, of small olive riddle turtles also possess biseriality of grooves and ridges across a long trackway axis, but are typically symmetrical for forward-walking life habits.

\section{DISCUSSION}

\section{Physiological and Other Requirements}

The formation of the longer version of trackways by adult Ocypode has been attributed to their specific brachyuran life habits (quasiterrestrial, side runner, endobenthic and soft shore dweller) and the physiological need for periodical gill moistening with life-saving saline seawater charged with dissolved oxygen. The morphological clues revealing the direction of continuous locomotion from land to seawater of the crabs confirm the involve- ment of the above physiological process. Similar but narrower trackways of shorter dimensions and freely-wandering to self-crossing or erratic types observed around intertidal burrow openings (Figure 5.5) have been attributed to other life functions (e.g., searching for food, dwelling place, etc.) than gill moistening. The young crabs thriving within the intertidal zone need not produce such long trackways as they can periodically reach tidal water within short distances, and their burrows get inundated regularly. The old and juvenile individuals prefer to capitalize burrow base water rather than to reach distant tidal water (De, 2000). In the study area ocypodid crabs, besides formation of various types of dwelling burrows, are known to produce at least eight types of surficial pelletal (feeding) ornamentations or designs especially in the upper intertidal zone. Their pellet making activities have been attributed to search for food and formation of burrow-guided pellet-walled radial runways required to hide into the burrow and concentric pathways to confuse or obstruct the predators (Chakraborty, 1970; De, 2000). It is thus obvious that variation in neoichnological features is largely caused by variable physiological and related requirements. There are fossil records of invertebrate and vertebrate trackways (Table 1) that largely focus on locomotion styles rather than actual physiological requirements involved in trackway formation.

Martin (2006) discussed different types of resting traces of ocypodid crabs and linked them to hydration and respiration. The present physiologi- 
cal attributes of exceptionally long Ocypode trackways, their morphological variations with respect to substrate environments, and orientation with respect to coast line and behavioural patterns involved in formation of associated shorter versions of trackways were never addressed before. However, physiological aspects of lungfish burrows (Hembree, 2010) and mollusk trails and tracks (Getty and Hagadorn, 2005); different locomotion styles (swimming-walking) involved in trilobite tracks and trackways (Seilacher, 2007; Crimes, 1975) and long vertebrate trackways attributed to rapid colonization and emigration (Gradziński and Uchman, 1994; Diedrich, 2008; Genise et al., 2009) are well known.

\section{Trackway Orientation}

The general orientation, which is observed here to be right across the shoreline of these long trackways (Figure 3.1 ), is primarily governed by energy conservation and urgency. The down the beach or cross-shore orientation of these trackways implies their urgency of availing life-saving seawater spending less time and energy and traveling the shortest possible distance for their survival. The orientation of the longer version of Ocypode trackways, thus, acquires several geomorphic connotations. The orientation constitutes a set of criteria important in palaeogeographic and palaeoshoreline interpretations as discussed later. The association of short-length trackways with illdefined orientation and freely-wandering nature (Figure 5.5) with the longer version will strengthen these interpretations.

\section{Trackway Length}

So far, the longest known continuous trackway (about $350 \mathrm{~m}$ long) is attributed to a late Cretaceous dinosaur in the Andes Mountains, Bolivia (Lockley et al., 2002; Dinosaur News, $15^{\text {th }}$ August, 1998 www.enchantedlearning.com/subjects/dinosaurs/news/Boliviatracks.shtml). Another sauropod footprint site from near Lyon, France, can rival the Bolivia occurrence (Science Daily, www.sciencedaily.com/releases/2009/10/

091009132928.htm). In the Toadstool Park of Nebraska, 1.2 kilometers long trackways of enteledonts (giant wild pigs), herds of rhinos, horses and oreodonts (hoofed mammals distantly related to modern camels and swine) collectively document preserved evidence of one of the longest migrations of vertebrates along a river course during the Eocene to Miocene times (Nixon and Lagarry, 1993). A 15 m long Devonian trackway of tetrapod from the Valentia Island, Ireland is known (Clack, 1997).

Invertebrate trackways of variable lengths are also known. A unique and complex $6 \mathrm{~m}$ long terrestrial trackway of a giant lumbering arthropod Hibbertopterus (Eurypterida: water scorpion) has been, so far, claimed to be the world's largest arthropod trackway (individual) from 330 million years old non-marine sandstone beds in Scotland (Whyte, 2005). Another large trackway Diplichnites cuithensis $(210 \mathrm{~cm}$ long) produced by giant myriapod-like terrestrial arthropod Arthropleura has been reported from the nonmarine redbeds of the Cutler Group (Late Pennsylvanian) in El Cobre Canyon, New Mexico (Lucas et al., 2005). The 10 $\mathrm{m}$ long crustacean trackway of Eocene Mithakhari Group of Andaman (author's recent observation) could be the longest ever fossil invertebrate trackway (Figure 4.6).

Amongst modern trackways, 20-30 m long individual trackway of bird is known from the Banas River Basin of Gujarat (De and Mathur, 2007). Published documents on the length of individual trackway of invertebrate origin are too rare, although they are being produced in large numbers and variety on varied substrate across a long environmental profile. The present Bakkhali features are, thus, considered to be the longest ever reported individual invertebrate trackway (amongst recent or ancient) of the world. They allow first ever detailing of modern crab trackways to evaluate their importance in the geological record and geotechnical fields.

\section{Preservation Potential}

The studied trackways have low preservation potential because of strong waves and winds. In particular, trackways are easily deleted after drying, when the sediments become less cohesive. However, field observation suggests that the trackways are partially preserved in supratidal biomats (Figure 5.6), especially under thin layers of fine wind-blown sands that cover dune and ripple troughs. Although taphonomic constraints largely reduce the preservation potential and hence, availability of such features in rock record, geological record of similar and equally or even more delicate features are available. Onychopterellan Eurypterid (Chelicerata: Eurypterida) locomotory traces or trackways Palmichnium capensis and Trilobita trackways Petalichnus brandenburgensis from the Table Mountain Group (Ordovician) of South Africa (Braddy and Almond, 1999); xiphosurid arthropod trackways Kouphichnium from a disused colliery tip 
in the Writhlington Geological Nature Reserve (Pollard and Hardy, 1991); arthropod trackways from the Virgilian Tonganoxie Sandstone Member of eastern Kansas (Buatois et al., 1998a, 1998b); delicate soft body impressions of Ediacaran biota including tentacles of jellyfish (De, 2003b; 2006a,b; 2009b); Quaternary crustacean trackways of the Banas River Basin of western India (De and Mathur, 2007) and $10 \mathrm{~m}$ long decapod trackways from the Eocene Mithakari Group of the Andaman Islands (Figure 4.6) resembling the present ones in terms of morphological delicacy are some exceptional examples in this context. Delicate arthropod trackways are also known to be preferentially preserved in lithographic limestones, estuarine and lacustrine biolaminites, Cambrian intertidal sands covered by protective microbial films and bioglued eolian dune sands (Seilacher, 2008). For these reasons, the Bakkhali trackways could cross the fossilization barrier under very specific conditions, although the preservation potential is very low. Moreover, the Banas and Andaman trackways are considered (see later) as the ancient analogues of the recent Bakkhali Ocypode trackways on the basis of morphological analogy. These modern and ancient examples support the perception that the delicate Bakkhali traces are preservable as rock records under suitable taphonomic conditions. If so, the present neoichnological study can well be extended especially to the crustacean trackway history of the geologic past and can address certain aspects of ichnotaxonomy, trackway-making life habits, palaeoenvironment, palaeogeomorphology, taphonomy, animal physiology and ethology following the basic principle "Present is the key to the past."

\section{Taphonomic and Ethological Variants}

Spontaneous modification of the trackways being produced in the field is found to be induced to a great extent by physical environmental factors like wind action, tidal sweeping, rising temperature, rate of evaporation, rain, moistness and sand-siltclay contents of the substrate, biomats, besides many others. The best impressed trackways (referred here as parent structure) are produced in moist $(20 \%$ to $30 \%$ water content) sandy substrates of the middle intertidal flat. The trackways exhibit all delicate morphological elements (Figures $3.3,4.1-5)$. With further increase as well as decrease in sediment-water content towards the lower intertidal and supratidal flats, respectively, the morphological details and sharpness of the parent structure deteriorate abruptly. The resultant structures look so different that taphonomic variants are produced (Figures 3.2, 3.4, 5.1-2). Gravitative collapse of wet and dry sands imposes indistinctiveness that advances with time. However, the variants can be linked to the parent structure (Figures 3.3, 4.1-5) on the basis of still exhibited basic morpho-characters such as linearity, asymmetry, biserial arrangement of crescent pedal groves bounded by arcuate ridges, medial discontinuous ridge and chain-like appearance. In the rock records, as exemplified by taphonomic variants of arthropod repichnial traces Dendroidichnites irregulare, Diplichnites gouldi and Diplichnites biformis from the Upper Carboniferous fluvio-estuarine palaeovalley of eastern Kansas (Buatois et al., 1998a, 1998b), each of these structures will constitute an individual ichnotaxonomic variant, although behavioural and physiological parameters and taxonomic identity of the trace producer remain unchanged. Other conditions, like best suited moist intertidal substrate (Figure 5.5, walking-running on toes with lifted body), substrate slope (Figure 5.3-4, walking-sliding down a dry dune slope and slow walking on flat and dry sandy surface) and biomat ground (Figure 5.6, slow walking over sticky and rippled biomat surface) result in varied walking styles and produce ethological variants. The longer versions of the present Ocypode trackways of Bakkhali beach pass through various substrate conditions and are thus, likely to produce ichnotaxonomic variants in the rock records on the other side of the taphonomic barrier.

\section{Comparable Recent and Ancient Trackways}

Published literatures on recent invertebrate trackways are too rare to find a match with the present features. Classical works of seventies and eighties on sedimentology, biology and organic activities of the Georgia coastal region, Sapelo Island, USA (Dörjes, 1972; Dörjes and Howard, 1975; and many others) provide no photographic representation of decapod trackways resembling the present ones. Moreover, features similar to the present Bakkhali trackways found no mention in the detailed and classified documentations of common modern and ancient invertebrate traces from terrestrial and coastal marine aquatic settings (Frey, 1975). Experimental neoichnological study, so far, involves trackways produced by various arthropod groups other than the decapods (Davis et al., 2007). However, various modern trackways of decapod crustacean (crabs) origin including that of Ocypode spp. have been described both from the Bay of Bengal and Arabian Sea coasts and 
Banas River basin of Gujarat, India (Bakshi, et al., 1980; De, 1995, 2000, 2005b; De and Mathur, 2007) and elsewhere (Frey et al., 1984) in other perspectives than that of the present paper.

Amongst documented fossil invertebrate trackways of non-arthropod origin it is difficult to find a feature morphologically comparable to the present ones. Some of the reported arthropod trackways (Braddy and Almond, 1999; Buatois and Mángano, 2002; Kim et al., 2005; Minter et al., 2007; Pollard et al., 2008; Seilacher, 2008; Uchman et al., 2009; Fillmore et. al., 2010) can at best be considered partially comparable to some of the wind-affected taphonomic variants of the present trackways. Arthropod trackways Palmichnium and Diplichnites from Devonian Muth Quartzite of the Spiti Valley, India (Draganits et al., 1998) do possess some morphological similarity (linearity, biserial crescent pedal groves and ridges across a medial flat ridge, persistent width and local twists and turns) with that of the present trackways. Repichnial (trackways) traces Dendroidichnites irregulare, Diplichnites gouldie, Diplichnites biformis, Kouphichnium isp and Stiallia pilosa of arthropod, limulid and insect origin described from the Upper Carboniferous fluvio-estuarine palaeovalley of eastern Kansas (Buatois et al., 1998a, 1998b) possess a better partial morphological resemblance to some of the longer versions of the Ocypode trackways of the Bakkhali beach. But none of the above invertebrate fossil trackways can be considered in sensu stricto as the ancient analogues of the Bakkhali trackways as they lack crucial morphological asymmetry. However, some of the Pleistocene-Holocene trackways of crustacean origin described from the Banas River basin of Gujarat (De and Mathur, 2007) and about $10 \mathrm{~m}$ long decapod trackways observed in the Eocene Mithakhari Group of sediments of Andaman and Nicobar Islands (Figure 4.6) bear closest possible morphological similarities to the present structures. The last two preserved examples that possess diagnostic structural asymmetry across the long axis have been considered here as the best possible ancient analogues of the modern Bakkhali trackways. This analogy justifies the preservation possibility, survivorship and application potentiality of the present trackways in the geologic past, especially to the post-Jurassic sequences, i.e., after the arrival of true decapods in the life history of arthropod.

\section{Geotechnical Appraisal}

Understanding and monitoring dynamic processes is crucial for coastal management. In particular, rate of deposition/erosion, substrate stability, beach slope and tidal range are important parameters for geotechnical applications. Application of modern biological tools has come to the rescue of common physical techniques that involve substantial input of time, labor and money. Among natural indicators, biogenic sedimentary structures (traces) found successful application in coastal geotechnics. The degree of bioturbation at sediment-water interface on a tidal flat $15 \mathrm{~km}$ away from the mainland coast (Reineck, 1977) was applied to solve a geotechnical problem involved in building a deep water harbor at the Elbe estuary (Germany). Some modern dwelling-feeding burrows of infaunal genus Mya (pelecypod), Nereis (polychaete) and Cerianthus (anemone) have been used for estimating rates of erosion and deposition (Goldring, 1964; Howard and Frey, 1975). Modern Diopatra cupria (polychaete worm) burrow tubes (agglutinated) of the study area have been applied as potential and reliable ichnological tools for precise and instantaneous estimation of current annual rates of deposition and erosion in the Bay of Bengal beaches (De, 2002a). Uca marionis mud volcanoes that distally associate long Ocypode trackways in the Bakkhali beach (Figure 2) are unique ichnological tools for demarcating unstable beach sectors (De, 2009a). Besides modern examples, U-shaped burrows Diplocraterion yoyo from the Baggy Beds of north Davon have been utilized for measuring deposition and erosion rates of the Late Devonian sea (Goldring, 1964; Howard and Frey, 1975). Shallow marine neoichnological features of infaunal origin are typically the products of complex interaction of physical (e.g., coastal dynamics, substrate rigidity, deposition - erosion, wave - wind actions etc.), biological (e.g., burrowing, boring, tracking, feeding etc.) and chemical (e.g., salinity, acidity, etc.) processes (De, 2000). Biochemical processes are also involved in the formation of biomats and pellets. The coastal neoichnological features, thus, bear the obvious fingerprints of these processes. The main task is to pick up the ichnological signals from the environmental noises for geotechnical and other purposes.

The very presence of Ocypode trackways and burrows, long or short, indicate a stable sandy beach. They need specific environmental conditions to settle their burrows: (a) moist sandy substrate without any clay partings, (b) accessible groundwater (less than $1-1.6 \mathrm{~m}$ of depth) and (c) 
pervious sand allowing accumulation of respiratory water at burrow base (De, 2000, 2005a). The longer version of Ocypode trackways traces the entire beach profile including its exposed width and slope. Variation in trackway morphology along its course indicates moistness conditions of substrate, as discussed before; helps demarcate supratidal flat and dune fields, intertidal and subtidal zones, and measure tidal range and water depth in time and space. The tidal range $(4-5 \mathrm{~m})$ as measured from the studied long trackways confirms mesotidal nature of the Bakkhali beach. Contrastingly, the Uca mud volcanoes at nearby areas are suggestive of most unstable beach portions (De, 2009a). Long trackways associated with biomats suggest areas of high firmness in overall stable beach. Total absence of such trackways in the Ocypode burrow zone (Figure 2) suggests either shallowness of the local groundwater level so that all burrow bases are full of respiratory water or rigorous eroding or reshuffling nature of the surficial sediment layers by wind and water actions. Geotechnical utility of the long trackways widens further when they are analyzed in collaboration with other associated neoichnological features. Wide zoogeographic distribution of Ocypode in tropical - subtropical coasts ensures universal application of their trackways as a new found ichnological tool.

Furthermore, lateral shift of the trackways through time and space would suggest the transgressive-regressive behaviour of the present and ancient sea. This information is mandatory for all coastal developmental projects. Their survivorship in the Tertiary marine basin could be utilized in identifying shallow basinal parts, basin margin and direction of deep basinal parts: that is the basic information required for oil exploration.

\section{GEOLOGICAL AND GEOTECHNICAL IMPORTANCE}

The results of this study are fundamental to the study of fossil decapods trackways and can be used in ichnotaxonomic revisions, taxonomic identification of trace fossil producers, palaeoecological and palaeogeographical reconstructions. It also elucidates physiological and preservation processes and facilitates geotechnical exploration.

\section{Ichnotaxonomy and Identity of Trackmakers}

On the basis of the present study, a set of basic morpho-characters can be assigned to the repichnial traces (trackways) of amphibious crab genera Ocypode that has a wide zoogeographical adaptation in the soft sandy coast of tropical and subtropical world. These characters are linearity and asymmetry, chain-like biserial arrangement of crescent pedal groves bounded by arcuate ridges, medial discontinuous ridge, persistent width and local maneuvering twists and turns (Figures 3.1, 4.1-5). However, some of these features are differentially modified (Figures 3.2, 3.4, 5.1-2) in response to varied environmental and taphonomic conditions. The modifications result in ichnotaxonomic (taphonomic) variants in the rock record as exemplified by the eastern Kansas Upper Carboniferous trackways (Buatois et al., 1998a, 1998b). The discussed architectural variations in the Ocypode trackways (Figures 3.1, 4.1, 5.3-5) due to varied behavioural or ethologic responses (e.g., herding for gill moistening vs. feeding and different walking styles on dry dune slope and sticky biomat) contributes ethological variants (e.g., long and straight cross-coast trackways vs. short, freely wandering and self crossing trackways) to ichnotaxonomy. On the basis of basic morphological similarity including asymmetry the mentioned Pleistocene-Holocene crustacean trackways described from the Banas River basin of Gujarat (De and Mathur, 2007) and 10m long decapod trackways of the Eocene Mithakhari sediments of Andaman and Nicobar Islands (Figure 4.6) can be attributed to side-runner crabs like Ocypode. They constitute nearest ancient analogues of the described Bakkhali trackways. These ancient trackways have remained, so far, ichnotaxonomically unnamed. The Upper Carboniferous arthropod trackways Dendroidichnites irregulare, Diplichnites gouldi and Diplichnites biformis of eastern Kansas (Buatois et al., 1998a, 1998b) do not possess structural asymmetry and hence, can not be considered as the ancient analogues of the Bakkhali trackways. As discussed earlier, there is no other fossil invertebrate trackways bearing exact morphological similarity, especially the asymmetry. The Dimorphichnus patterns of Silurian trilobite traces (Seilacher, 2007) include some segments of asymmetric trackways. Such traces simply reflect an abrupt switch from a usual oblique motion (Diplichnites pattern) to perfect sidling (i.e., behavioral variants). The discussed Ocypode trackways are characteristically asymmetric all along their length in spite of frequent twists and turns since they are side-runners. The present study, thus, provides a set of new ichnological features that in post-Jurassic rock record deserve erection of new ichnotaxonomic elements both as taphonomic and ethological variants that are genetically linked with amphibious side-runner 
TABLE 2. Ichnological clues of crab trackways to basinal geomorphology.

\begin{tabular}{|l|l|}
\hline \multicolumn{1}{|c|}{ Ichnological clues } & Possible geomorphic implications \\
\hline Large burrow opening connected with outgoing long trackways & $\begin{array}{l}\text { Supratidal zone, land - sea (burrow mouth to trackway) directions and } \\
\text { shoreline orientation (across the trackway) }\end{array}$ \\
\hline Maximum length of individual trackway & Minimum beach width up to the then water level \\
\hline End point of longest trackway & Low tide level \\
\hline Best preserved segment of the long trackway & Stretch of moist intertidal flat or biomat substrate \\
\hline Least preserved segment of the long trackway & Dry supratidal flat to coastal dune sand or too moist lower intertidal flat \\
\hline Larger twists and turns of the long trackway & Positions of steep obstructions like dunes that are maneuvered \\
\hline Overall slope of the long trackway on single surface & Local beach slope \\
\hline $\begin{array}{l}\text { Length vs. slope of the best and least preserved segments of the long } \\
\text { trackway }\end{array}$ & Approximate tidal range and width of the supratidal and intertidal flats \\
\hline
\end{tabular}

crabs like Ocypode. This time connotation is supported by the fact that true crabs appeared only after Jurassic and side-running habit developed in Tertiary (Frey et al., 1984). That is why all the known Devonian and Carboniferous arthropod trackways (i.e., repichnial ichnotaxon) could not be attributed to side-runner crabs. The presented data, thus, help in ichnotaxonomic revision (erection of new ichnotaxon) and recognition of taxonomic identification of the ancient trace makers.

\section{Palaeoecology}

Ecologically the Ocypode crabs are best adapted to the mangrove-vegetated sandy and mesotidal delta-front beaches of the Bay of Bengal and Arabian Sea coasts of southeastern Asia and elsewhere in the tropical and sub-tropical soft beaches of the world. These adaptation specialties allow palaeoecological interpretation of their trackways in Tertiary and Quaternary rock records, even if the producer is not bodily preserved. The Eocene palaeoecology of Andaman and Quaternary highstand palaeoecology of the western Indian Banas River Basin (De and Mathur, 2007), as evidenced otherwise by body fossil and ichnofossil records, favour the above statement.

\section{Palaeogeomorphology}

The modern habitat pattern and long trackway-making activity of the Ocypode crabs, as discussed here earlier, provides many crucial ichnological clues (Table 2) to geomorphology of both recent and ancient depositional basins. Besides, many more supplementary and collaborative interpretations can also be made with the help of present data.

In a broader perspective, the presented ichnological database can be used in palaeogeographic reconstruction of sedimentary basin, especially delineation of palaeoshoreline, basin configuration and land-sea distribution.

\section{Physiology and Life Habits}

The present study also provides valuable clues to the physiological requirements, walking style and some other behavioral patterns of the crabs making such long, parallel and asymmetric trackways. Very long and mutually parallel trackways are not unknown in the rock records. Some of the sites indicate selective herding, migratory and colonization behavior of the ancient trackers. In the Germanic Basin of central Europe, for example, Early to Middle Triassic carbonate tidal flats preserve millions of small- to medium-sized reptile tracks that parallel and head to the same direction. During lowstands these tidal flats acted as interpeninsula bridges, which allowed herding and migration of reptiles (Diedrich, 2008). The tetrapod footprints and invertebrate burrows in the interdune deposits of the Lower Triassic Tumlin Sandstone of Central Poland show an $r$-selected strategy in rapid colonization of interdunal ecospace (Gradziński and Uchman, 1994). The present study relates the inherent physiological need of amphibious crabs, i.e., periodic and compulsive gill moistening with seawater, with their asymmetric, long and parallel trackways selectively across the shoreline. Parallel evidence of physiological appraisal of ancient crab trackways is extremely rare (Martin, 2006; Netto and Grangeiro, 2006). Getty and Hagadorn (2005) discussed surface tracks and trails of mollusk having physiological capacity to manipulate sediment to produce the structures. Aestivation burrows of lungfish, earthworm, lysorophid and dicynodont have been attributed to a physiological need of retaining body water content during extremely dry (draught) situations (Hembree, 2010).

Fossil records of long vertebrate trackways are largely attributed to emigration and colonization 
rather than physiology (Diedrich, 2008; Gradziński and Uchman, 1994). The studied crab trackways do not represent such emigration or colonization. Localized short-length trackways with ill-defined orientation, self crossing and freely wandering nature when produced around burrow mouths (Figure 5.1) are attributable to other life functions (e.g., feeding and pellet making etc.) than gill moistening. The observed criteria are also applicable to geological past in cases of suitable preservation. The direction of movement of the ancient tracker can be deciphered from the trackway morphology. The marginal ridges and grooves show strong forward curvature such that their narrower ends point backward (Figure 4.1-5). The understanding of animal physiology and life habits from the trackway morphology, as recorded in the Bakkhali traces, constitutes a part of fundamental research in ichnology and adds new ideas to the basic ichnological database for application to geologic past.

\section{Geotechnical Applications}

The long trackways and burrows of Ocypode can be used independently as a new ichnological tool to identify stable sandy beach. The trackways measure its exposed width and slope, besides delineation and substrate characterization of coastal geomorphic units and landforms (dry sandy supratidal zone with different geomorphic units including dune fields and biomats, and moist intertidal and subtidal zones, etc.) and measurement of tidal range and water depth in time and space, i.e., information mandatory in coastal geotechnical exploration works. The absence of long trackways suggests either the shallowness of the local groundwater level or presence of concomitant wind and water actions that actively reshuffle the surficial sediment layers erasing the delicate trackways. The extent of trackway production, preservation and survivorship provide ideas about the strength and nature of coastal dynamic processes. Wide zoogeographic distribution of Ocypode in tropical - subtropical coasts and intimate and ubiquitous association of their trackways with other decapod lebensspuren enhance their scope for wider geotechnical applications. Moreover, their preservation in the Tertiary marine basin may have applied value in oil exploration as they reveal shallow and deep sea positions. Lateral shift of long trackways over time and space would suggest the transgressive or regressive mode of sea: very crucial information required for any coastal developmental project.

\section{ACKNOWLEDGEMENT}

The author thankfully acknowledges the administrative support and logistics provided by the Director General of the Geological Survey of India, Central Headquarters, Kolkata, India, for taking up the field work in the Bay of Bengal coast

\section{REFERENCES}

Anfinson, O.A., Lockley, M.G., Kim, S.H., Kim, K.S., and $\mathrm{Kim}$, J.Y. 2009. First report of the small bird track Koreanaornis from the Cretaceous of North America: implications for avian ichnotaxonomy and paleoecology. Cretaceous Research, 30:885-894.

Ataabadi, M.M. and Sarjeant, W.A.S. 2000. Eocene mammal footprints from Eastern Iran: a preliminary study. Comptes Rendus de l'Académie des Sciences - Series IIA - Earth and Planetary Science, 331:543547.

Bakshi, S.K., Ray, T.K., and De, C. 1980. On the workings of some crabs on the sandy beach of western Sundarban, Bengal Delta, India. Journal of the Geological Society of India, 21:184-187.

Bandopadhaya, A. and De, C. 2000. Algal micro-boring on ooids: an evidence of Holocene sea transgression in Eastern India. Indian Journal of Marine Science, 29:181-184.

Benner, J.S., Ridg, J.C., and Taft, N. K. 2008. Late Pleistocene freshwater fish (Cottidae) trackways from New England (USA) glacial lakes and a reinterpretation of the ichnogenus Broomichnium Kuhn. Palaeogeography Palaeoclimatology Palaeoecology, 260:375-388. www.sciencedirect.com/science/article/ $\mathrm{pii} / \mathrm{S} 0031018208000126$

Braddy, J. and Almond, J.E. 1999. Eurypterid trackways from the Table Mountain Group (Ordovician) of South Africa. Journal of African Earth Sciences, 29:165177.

Buatois, L.A. and Mángano, M.G. 2002. Trace fossils from Carboniferous floodplain deposits in western Argentina: implications for ichnofacies models of continental environments. Palaeogeography Palaeoclimatology Palaeoecology, 183:71-86.

Buatois, L.A., Mángano, M.G., Maples, C.G., and Lanier, W.P. 1998a. Allostratigraphic and sedimentologic applications of trace fossils to the Study of Incised Estuarine valleys: An example from the Vergilian Tonganoxie Sandstone member of Eastern Kansas. Current Research in Earth Sciences, 241:1-27.

Buatois, L.A., Mángano, M.G., Maples, C.G., and Lanier, W.P. 1998b. Ichnology of an Upper Carboniferous fluvio-estuarine paleovalley: The Tonganoxie sandstone, Buildex quarry, Eastern Kansas, USA. Journal of Palaeontology, 72:152-180.

Chakraborty, A. 1970. Beach structure produced by crab pellets. Sedimentology, 18:129-134. 
Chattopadhaya, G., Chakraborty, A., and Hertweck, G. 1993. Biogenic structures related to feeding activities of Macoma Birmanica from the Mangrove area of the Sagar Island, NE India, Senckembergiana Maritima, 23:99-107.

Clack, J.A. 1997. Devonian tetrapod trackways and trackmakers; a review of the fossils and footprints. Palaeogeography Palaeoclimatology Palaeoecology, 130:227-250.

Costa da Silva, R., Ferigolo, J., Ismar de Souza, C., and Fernandes, A.C.S. 2008. Lacertoid footprints from the Upper Triassic (Santa Maria Formation) of Southern Brazil. Palaeogeography Palaeoclimatology Palaeoecology, 262:140-156.

Crimes, T.P. 1975. The production and Preservation of trilobite resting and furrowing traces. Lethaia, 8:3548.

Davis, R.B., Minter, N.J., and Braddy, S.G. 2007. The neoichnology of terrestrial arthropods. Palaeogeography Palaeoclimatology Palaeoecology, 255:284307.

De, C. 1995. Environmental significance of the Quaternary lebensspuren of the Banas River Basin of Gujarat, India. Indian Minerals, 49:13-30.

De, C. 2000. Neoichnological activities of endobenthic invertebrates in downdrift coastal Ganges Delta Complex, India: Their significance in trace fossil interpretations and paleoshoreline reconstructions. Ichnos, 7:89-113.

De, C. 2002a. Application of biological tool for estimating annual rates of erosion and deposition in modern coastal environments: a case study in the Bay of Bengal coast. Marine Georesources and Geotechnology, 20:209-220.

De, C. 2002b. Continental mayfly burrows within relictground in inter-tidal beach profile of Bay of Bebgal coast: a new ichnological evidence of Holocene marine transgression. Current Science, 83:64-67.

De, C. 2003a. Ichnological evidences of Holocene marine transgression in the Bay of Bengal Coast, West Bengal, India. Proceedings of GEOSAS Seminar, New Delhi: 302-311.

De, C. 2003b. Possible organisms similar to Ediacaran forms from the Bhander Group, Vindhyan Supergroup, Late Neoproterozoic of India. Journal of Asian Earth Sciences, 21:387-395.

De, C. 2005a. Biophysical model of intertidal beach crab burrowing: Application and significance. Ichnos, 12:1-19.

De, C. 2005b. Quaternary ichnofacies model for Palaeoenvironmental and Paleosealevel interpretations: a study from the Banas River Basin, western India. Journal of Asian Earth Sciences, 25:233-249.

De, C. 2006a. Ediacara fossil assemblage in the upper Vindhyans of central India and its significance. Journal of Asian Earth Sciences, 27:660-683.

De, C. 2006b. Vindhyan trace fossils, dubiofossils and pseudofossils in the light of advent and early evolution of metazoans. Indian Minerals, 60:1-38.
De, C. 2009a. Uca marionis Mud Volcanoes: a unique Ichnological Tool from the Bay of Bengal Coast of India for Ready Assessment of Beach Stability. Marine Georesources and Geotechnology, 27:1-17.

De, C. 2009b. The Vindhyan Ediacaran fossil and trace fossil assemblages: their insight into early metazoan palaeobiology, palaeobiogeography and Vindhyan biostratigraphy. Indian Journal of Geosciences, 63:11-40.

De, C. and Mathur, U.B. 2007. Quaternary geological evolution of Gujarat with special reference to the inland Banas river basin and Bhavnagar coast, Gujarat, western India. Memoir Geological Survey of India, 134:1-134.

Deb, M. 1998. Faunas of West Bengal. Part Crustacea: Decapoda: Crabs. Zoological Survey of India, Kolkata. State Fauna Series, 3:345-403.

Demathieu, G.R. and Wycisk, P. 1990. Tetrapod trackways from Southern Egypt and Northern Sudan. Journal of African Earth Sciences, 10:435-443.

Diedrich, C. 2008. Millions of reptile tracks - Early to Middle Triassic carbonate tidal flat migration bridges of Central Europe - reptile immigration into the Germanic Basin. Palaeogeography Palaeoclimatology Palaeoecology, 259:410-423.

Dörjes, J. 1972. Georgia coastal region, Sapelo Island, U.S.A., sedimentology and biology, VII. Distribution and Zonation of macrobenthic animals. Senckembergiana Maritima, 4:183-216.

Dörjes, J. and Howard, J.D. 1975. Estuaries of the Georgia coast, U.S.A. sedimentology and Biology, IV. Fluvial marine transition indicators in an estuarine envrionment, Ogeechee River, Ossabaw sound. Senckembergiana Maritima, 7:137-179.

Draganits, E., Grasemann, B., and Braddy, S.J. 1998. Discovery of abundant arthropod trackways in the Lower Devonian Muth Quartzite (Spiti, India): implications for the depositional environment. Journal of Asian Earth Sciences, 16:109-118.

Fillmore, D.L., Lucas, S.G., and Simpson, E.L. 2010. Invertebrate trace fossils in semi-arid to arid braidedephemeral-river deposits of the Mississippian middle member of the Mauch Chunk Formation, eastern Pennsylvania, USA. Palaeogeography Palaeoclimatology Palaeoecology, 292: 222-244.

Fornós, J.J., Bromley, R.G., Clemmensen, L.B., and Rodríguez-Perea, A. 2002. Tracks and trackways of Myotragus balearicus Bate (Artiodactyla, Caprinae) in Pleistocene aeolianites from Mallorca (Balearic Islands, Western Mediterranean). Palaeogeography Palaeoclimatology Palaeoecology, 180:277-313.

Frey, R.W. 1975. The study of trace fossils. Springer Verlag, New York.

Frey, R.W., Curran, H.A., and Pemberton, S.G. 1984. Trace making activities of crabs and their environmental significance. Ichnogenus Psilonichnus. Journal of Palaeotology, 58:333-350. 
Genise, J.F., Melchor, R.N., Archangelsky, M., Bala, L.O., Straneck, R. and de Valais, S. 2009. Application of neoichnological studies to behavioural and taphonomic interpretation of fossil bird-like tracks from lacustrine settings: The Late Triassic-Early Jurassic? Santo Domingo Formation, Argentina. Palaeogeography Palaeoclimatology Palaeoecology, 272:143161.

Getty, P.R. and Hagadorn, J.W. 2005. Small Climatichnites trackways: their abundance and implications for trackmaker physiology. GSA 2005, Salt Lake City Annual Meeting (October 16-19, 2005)

Goldring, R. 1964. Trace-fossils and the sedimentary surface in shallow-water marine sediments, p.136143. In Van Straaten, L.M.J.U. (ed.), Deltaic and Shallow Marine Deposits. Elsevier, Amsterdam.

Gradziński, R. and Uchman, A. 1994.Trace fossils from interdune deposits-an example from the lower triassic aeolian Tumlin Sandstone, central Poland. Palaeogeography Palaeoclimatology Palaeoecology, 108:121-138.

Hembree, D.I. 2010. Aestivation in the fossil record: evidence from ichnology. Program Molecular Subcell Biology, 49:245-262. doi: 10.1007/978-3-642-024214_12.

Howard, J.D. and Frey, R.W. 1975. Estuaries of the Georgia coast, U. S. A. Sedimentology and Biology II. Regional Animal-Sediment Characteristics of Georgia Estuaries. Senckembergiana Maritima, 7:297-305.

Jacobs, Z. and Roberts, D.L. 2009. Last Interglacial Age for aeolian and marine deposits and the Nahoon fossil human footprints, Southeast Coast of South Africa. Quaternary Geochronology, 4:160-169.

Kim, J.Y., Keighley, D.G., Pickerill, R.K., Hwang, W., and Kim, K.S. 2005. Trace fossils from marginal lacustrine deposits of the Cretaceous Jinju Formation, southern coast of Korea. Palaeogeography Palaeoclimatology Palaeoecology, 218:105-124.

Kim, J.Y., Kim, K.S., Lockley, M.G., Yang, S.Y., Seo, S.J., Choi H. II., and Lim, J.D. 2008. New didactyl dinosaur footprints (Dromaeosauripus hamanensis ichnogen. et ichnosp. nov.) from the Early Cretaceous Haman Formation, south coast of Korea. Palaeogeography Palaeoclimatology Palaeoecology, 262:7278.

Kuban, G.J. 2009. An Overview of Dinosaur Tracking. Originally published in the April 1994. M.A.P.S. Digest, Mid-America Paleontology Society, Rock Island, IL. paleo.cc/paluxy/ovrdino.htm

Lee, Y-N., Lee, H-J., Lü, J., and Kobayashi, Y. 2008. New pterosaur tracks from the Hasandong Formation (Lower Cretaceous) of Hadong County, South Korea. Cretaceous Research, 29:345-353.

Lockley, M.G., Schulp, A.S., Meyer, C.A., Leonardi, G., and Mamani, D.K. 2002. Titanosaurid trackways from the Upper Cretaceous of Bolivia: evidence for large manus, wide-gauge locomotion and gregarious behaviour. Cretaceous Research, 23:383-400.
Lockley, M.G., Houck, K., Yang, S-Y., Matsukawa, M., and Lim, S-K. 2006a. Dinosaur-dominated footprint assemblages from the Cretaceous Jindong Formation, Hallyo Haesang National Park area, Goseong County, South Korea: Evidence and implications. Cretaceous Research, 27:70-101.

Lockley, M.G., Matsukawa, M., Ohira, H., Li, J., Wright, J., White, D., and Chen, P. 2006b. Bird tracks from Liaoning Province, China: New insights into avian evolution during the Jurassic-Cretaceous transition. Cretaceous Research, 27:33-43.

Lucas, S.G., Lerner, A.J., Hannibal, J.T., Hunt, A.P., and Schneider, J.W. 2005. Trackway of a giant Arthropleura from the Upper Pennsylvanian of El Cobre Canyon, New Mexico. New Mexico Geological Society, 56th Field Conference Guidebook, Geology of the Chama Basin, 279-282.

Mallick, T.K. 1976. Shelf sediments on the Ganges Delta. Marine Geology, 22:1-32.

Martin, A.J. 2006. Resting Traces of Ocypode quadrata Associated with Hydration and Respiration: Sapelo Island, Georgia, USA. Ichnos, 13:57-67.

Min Huh, Paik, I.S., Lockley, M.G., Hwang, K.G., Kim, B.S., and Kwak, S.K. 2006. Well-preserved theropod tracks from the Upper Cretaceous of Hwasun County, southwestern South Korea, and their paleobiological implications. Cretaceous Research, 27:123-138.

Minter, N.J., Braddy, S.J., and Davis, R.B. 2007. Between a rock and a hard place: arthropod trackways and ichnotaxonomy. Lethaia, 40:365-375.

Nagelkerken, I., Blaber, S.J.M., Bouillon, S., Green, P., Haywood, M., Kirton, L.G., Meynecke, J-O., Pawlik, J., Penrose, H.M., Sasekumar, A., and Somerfield, P.J. 2008. The habitat function of mangroves for terrestrial and marine fauna: A review. Aquatic Botany, 89:155-185.

Netto, R.G. and Grangeiro, M.E. 2009. Neoichnology of the seaward side of Peixe Lagoon in Mostardas, southernmost Brazil: the Psilonichnus ichnocoenosis revised. Revista Brasileira De Paleontologia, 12:211224.

Nixon, D. and Lagarry, H. 1993. New trackway site in the White River Group type section at Toadstool Park, Nebraska: paleoecology of an Oligocene braided stream, riparian woodland, and adjacent grassland. Journal of Vertebrate Paleontology, 13:50.

Pollard, J.H. and Hardy, P.G. 1991. Trace fossils from the Westphalian D of Writhlington Geological Nature Reserve, nr. Radstock, Avon. Proceedings of the Geologists' Association, 102:169-178.

Pollard, J., Selden, P., and Watts, S. 2008. Trace fossils of the arthropod Camptophyllia from the Westphalian (Carboniferous) rocks of Lancashire, UK and their palaeoenvironmental context. Palaeogeography Palaeoclimatology Palaeoecology, 270:399-406. 
Reineck, H.E. 1977. Natural indicators of energy level in Recent sediments: The application of ichnology to a coastal engineering problem, p. 265-272. In Crimes, T.P. and Harper, J.C. (eds.), Trace Fossils 2. Seel House Press, Liverpool.

Reineck, H.E. and Singh, I.B.1973. Depositional sedimentary environments. Springer Verlag, New York.

Roberts, D.L., Bateman, M.D., Murray-Wallace, C.V., Carr, A.S., and Holmes, P.J. 2008. Last Interglacial fossil elephant trackways dated by OSL/AAR in coastal aeolianites, Still Bay, South Africa. Palaeogeography Palaeoclimatology Palaeoecology, 257:261279.

Schopf, J.W. and Klein, C. 1992. The Proterozoic Biosphere: A Multidisciplinary Study. Cambridge University Press, Cambridge.

Sarjeant, W.A. and Mossman, D.J. 1978. Vertebrate footprints from the carboniferous sediments of Nova Scotia: A historical review and description of newly discovered forms. Palaeogeography Palaeoclimatology Palaeoecology, 23:279-306.
Scrivner, P.J. and Bottjer, D. J. 1986. Neogene avian and mammalian tracks from Death Valley National Monument, California: Their context, classification and preservation. Palaeogeography Palaeoclimatology Palaeoecology, 57:285-331.

Seilacher, A. 2007. Trace Fossil Analysis. Springer-Verlag, Berlin, Heidelberg, New York.

Seilacher, A. 2008. Biomats, biofilms, and bioglue as preservational agents for arthropod trackways. Palaeogeography Palaeoclimatology Palaeoecology, 270:252-257.

Uchman, A., Kazakauskas, V., and Gaigalas, A. 2009. Trace fossils from Late Pleistocene varved lacustrine sediments in eastern Lithuania. Palaeogeography Palaeoclimatology Palaeoecology, 272:199-211.

Whyte, M.A. 2005. Palaeoecology: A gigantic fossil arthropod trackway. Nature, 438:576. 